\title{
Tinjauan Yuridis Interaksi Manusia Terhadap Digital Dalam Penegakan Hukum Di Era Revolusi Industri 4.0
}

\author{
AriDermawan', Sumantri' ${ }^{2}$, Sudarmin ${ }^{3}$, Indra Ramadona Harahap4 \\ ${ }^{1,4}$ Program Studi Manajemen Informatika STMIK ROYAL Kisaran \\ 2,3Program Studi Sistem Informasi STMIK ROYAL Kisaran \\ E-mail : aridermawan451@gmail.com, sumantrisuherman35@mail.com, \\ edisudarmindra@gmail.com,ir.harahapma@gmail.com
}

\begin{abstract}
Abstrak-Human and computer interaction or human computer interaction or abbreviated as HCI is a discipline that studies the relationship between humans and computers. Human to digital interactions are increasing according to human needs that are increasingly complex. At present the world community has entered the stage of industrial revolution 4.0, and law enforcement is needed so that in the Era of the industrial revolution 4.0. get legal certainty in using digital technology or computer technology. As for the formulation of the problem is the Juridical Review of Human Interaction on Digital in Law Enforcement in the Age of Industrial Revolution 4.0, How the causes of misuse of Human Interaction Against Digital in the Age of Industrial Revolution 4.0, and How to prevent abuse of Human Interaction against Digital in the Era of Industrial Revolution. The research methodology uses normative research and library research data collection tools. Human Interaction Against Digital in Law Enforcement In the Age of Industrial Revolution 4.0 the legal foundation is needed, namely the Criminal Code and Law Number 11 of 2008 concerning Information and Electronic Transactions. Causes of Abuse of Human Interaction Against Digital in the Era of Industrial Revolution 4.0. among others are unlimited internet access. Efforts to Prevent Abuse of Human Interaction Against Digital in the Era of Industrial Revolution 4.0 can be done with the support of special institutions, both state-owned and NGOs (Non Governmental organizations).
\end{abstract}

Keywords : Juridical Review, Human Interaction, Law Enforcement

Abstrak-Interaksi manusia dan komputer atau human computer interaction atau disingkat HCI adalah disiplin ilmu yang mempelajari hubungan antara manusia dan komputer. Interaksi manusia terhadap digital semakin meningkat sesuai kebutuhan manusia yang semakin kompleksitas. Saat ini masyarakat dunia sudah masuk dalam tahap revolusi industri 4.0, dan diperlukan suatu penegakan hukum sehingga di Era revolusi industri 4.0. mendapat kepastian hukum dalam menggunakan teknologi digital atau teknologi komputer. Adapun yang menjadi rumusan masalah adalah Bagaimana Tinjauan Yuridis Interaksi Manusia Terhadap Digital Dalam Penegakan Hukum Di Era Revolusi Industri 4.0, Bagaimana penyebab terjadinya penyalahgunaan Interaksi Manusia Terhadap Digital di Era Revolusi Industri 4.0, dan Bagaimana upaya pencegahan penyalahgunaan Interaksi Manusia Terhadap Digital di Era Revolusi Industri 4.0. Metodologi penelitian menggunakan jenis penelitian normatif dan alat pengumpul data penelitian Kepustakaan. Interaksi Manusia Terhadap Digital dalam Penegakan Hukum Di Era Revolusi Industri 4.0 perlu landasan hukum yaitu KUHP dan Undang-Undang Nomor 11 Tahun 2008 tentang Informasi dan Transaksi Elektronik. Penyebab terjadinya Penyalahgunaan Interaksi Manusia Terhadap Digital di Era Revolusi Industri 4.0. antara lain yaitu Akses internet yang tidak terbatas. Upaya Pencegahan Penyalahgunaan Interaksi Manusia Terhadap Digital di Era 
Revolusi Industri 4.0 dapat dilakukan dengan dukungan lembaga khusus, baik milik negara maupun NGO (Non Goverment organization).

Kata Kunci : Tinjauan Yuridis, Interaksi Manusia, Penegakan Hukum

\section{PENDAHULUAN}

Interaksi manusia terhadap digital semakin meningkat sesuai kebutuhan manusia yang semakin kompleksitas. Saat ini masyarakat dunia sudah masuk dalam tahap revolusi industri 4.0, dimana kecanggihan teknologi internet menjadi pertanda yang sangat mengemuka. Teknologi tidak sekadar instrumen yang membantu manusia melaksanakan tugas-tugas yang kompleks, tetapi memiliki dampak perubahan revolusioner dalam pola berpikir dan berperilaku manusia serta budaya dan peradaban masyarakat. Teknologi digital saat ini tentunya memiliki efek positif dan negatif, bagaikan dua sisi mata pisau. Interaksi manusia dan komputer atau human computer interaction atau disingkat HCI adalah disiplin ilmu yang mempelajari hubungan antara manusia dan komputer yang meliputi perancangan, evaluasi, dan implementasi antarmuka pengguna komputer agar mudah digunakan oleh manusia. Ilmu ini berusaha menemukan cara yang paling efisien untuk merancang pesan elektronik. Sedangkan interaksi manusia dan komputer sendiri adalah serangkaian proses, dialog dan kegiatan yang dilakukan oleh manusia untuk berinteraksi dengan komputer yang keduanya saling memberikan masukan dan umpan balik melalui sebuah antarmuka untuk memperoleh hasil akhir yang diharapkan. Perkembangan kemajuan teknologi telah memberikan dampak yang signifikan terhadap kehidupansosial. Di seluruh dunia, teknologi menawarkan banyak fasilitas yang terutama melalui konektivitas internet sehingga memudahkan orang untuk mendapat akses atas data dan informasi termasuk data privasi seseorang secara lebih mudah (Sinta Dewi Rosadi 2015 , 4). Komputer adalah peralatan elektronik, magnetik, optikal, elektrokimia atau alat pengolah data berkecepatan tinggi yang dapat melakukan penalaran, atau fungsi penyimpanan, yang meliputi fasilitas penyimpanan atau komunikasi yang secara langsung berhubungan denga pengaoperasian peralatan secara terpadu, tetapi istilah tersebut tidak meliputi mesin ketik atau mesin ketik elekronik, kalkulator jinjing, atau alat serupa lainnya (widodo 2009, 25). Interaksi hubungan manusia dengan digital atau perkembangan teknologi komputer harus mewujudkan etika kehidupan yang beradap sehingga aturan yang terdapat dalam menggunakan digital tidak menggangu privasi orang lain. Interaksi hubungan manusia dengan digital juga harus sesuai dengan aturan undang-undang yang sesuai batasan yang dibuat pemerintah. Tujuan utama disusunnya berbagai cara interaksi manusia dan komputer adalah sebagai tujuan untuk mempermudah manusia dalam mengoperasikan komputer dan mendapatkan berbagai umpan balik yang ia perlukan selama ia bekerja pada sebuah sistem komputer. Para perancang antarmuka manusia dan komputer berharap agar sistem komputer yang dirancangnya dapat bersifat akrab dan ramah dengan penggunanya serta mudah digunakan. Akan tetapi didalam kemudahan tersebut perlu juga di beri pengamanan-pengamanan agar tidak melanggar hukum dan aturan yang berlaku. Kita butuh Interaksi manusia komputer adalah agar kita lebih cepat dalam 
menyelesaikan suatu pekerjaan. serta dapat membuat waktu pengerjaannya lebih cepat dan tidak membutuhkan banyak biaya dalam membuat suatu pekerjaan.

Perkembangan teknologi informasi dan komunikasi telah pula menyebabkan hubungan dunia menjadi tanpa batas (borderless) dan menyebabkan perubahan sosial, ekonomi, dan budaya secara signifikan berlangsung demikian cepat. Teknologi Informasi saat ini menjadi pedang bermata dua karena selain memberikan kontribusi bagi peningkatan kesejahteraan, kemajuan, dan peradaban manusia, sekaligus menjadi sarana efektif perbuatan melawan hukum. Memasuki abad ke-21 sangat banyak sekali perubahan khususnya dibidang teknologi dan informasi. Hampir semua orang di dunia menggunakan teknologi, tidak terlepas dengan negara Indonesia. Adanya teknologi yang semakin berkembang pesat tentunya juga banyak celah-celah kejahatan yang sering dilakukan. Apalagi kejahatan tersebut tidak terlihat kasat mata yang kadang kita juga tidak menyadarinya. Kejahatan yang seperti ini seringkali menjadi ketertarikan tersendiri oleh orang-orang yang tidak bertanggungjawab, apalagi seiring tidak mengertinya penegak hukum dalam memahami teknologi. Sehingga sistem proteksi yang sangat lemah dari berbagai macam produk yang masuk ke Indonesia. Apalagi jika kejahatan dalam dunia cyber berbentuk korporasi maka akan lebih berbahaya dan sangat sulit untuk membuktikannya. Saat ini telah lahir suatu rezim hukum baru yang dikenal dengan hukum siber atau hukum telematika. Hukum cyber atau cyber law, secara internasional digunakan untuk istilah hukum yang terkait dengan pemanfaatan teknologi informasi dan komunikasi. Demikian pula, hukum telematika yang merupakan perwujudan dari konvergensi hukum telekomunikasi, hukum media, dan hukum informatika. Istilah lain yang juga digunakan adalah hukum teknologi informasi (law of information technology) dan hukum dunia maya (virtual world law). Kegiatan melalui media sistem elektronik, yang disebut juga ruang siber (cyber space), meskipun bersifat virtual dapat dikategorikan sebagai tindakan atau perbuatan hukum yang nyata. Secara yuridis kegiatan pada ruang siber tidak dapat didekati dengan ukuran dan kualifikasi hukum konvensional saja sebab jika cara ini yang ditempuh akan terlalu banyak kesulitan dan hal yang lolos dari pemberlakuan hukum. Kegiatan dalam ruang cyber adalah kegiatan virtual yang berdampak sangat nyata meskipun alat buktinya bersifat elektronik. Dengan demikian, subjek pelakunya harus dikualifikasikan pula sebagai Orang yang telah melakukan perbuatan hukum secara nyata. Dalam kegiatan e-commerce antara lain dikenal adanya dokumen elektronik yang kedudukannya disetarakan dengan dokumen yang dibuat di atas kertas. Berkaitan dengan hal itu, perlu diperhatikan sisi keamanan dan kepastian hukum dalam pemanfaatan teknologi informasi, media, dan komunikasi agar dapat berkembang secara optimal. Oleh karena itu, terdapat tiga pendekatan untuk menjaga keamanan di cyber space, yaitu pendekatan aspek hukum, aspek teknologi, aspek sosial, budaya, dan etika. Untuk mengatasi gangguan keamanan dalam penyelenggaraan sistem secara elektronik, pendekatan hukum bersifat mutlak karena tanpa kepastian hukum, persoalan pemanfaatan teknologi informasi menjadi tidak optimal.

Melihat kondisi di atas diperlukan suatu perangkat aturan yang khusus mengatur agar interaksi manusia menggunakan teknologi komputer atau digital 
sesuai aturan hukum, saat ini memasuki Era Revolusi Industri 4.0 begitu banyak jenis tindak kejahatan dalam dunia teknologi digital. Untuk mengatasi berbagai permasalahan di atas pemerintah pada tanggal 21 April 2008 telah mengundangkan Undang-undang Nomor 11 Tahun 2008 tentang Informasi dan Transaksi Elektronik (UU ITE). Secara umum Undang-undang Nomor 11 Tahun 2008 tentang Informasi dan Transaksi Elektronik (UU ITE) dapat dibagi dua bagian besar yaitu mengatur mengenai transaksi elektronik dan mengatur perbuatan yang dilarang (cybercrimes). Upaya perlindungan korban sebenarnya sangat penting. Karena di samping dapat mengurangi penderitaan korban atas tindak pidana yang dialaminya, juga dapat mencegah terjadinya korban yang berkelanjutan, sehingga hal ini dapat mengurangi tingkat kriminalitas (Barda Nawawi Arief 2000, 3). Oleh sebab itu Penulis merasa penting untuk melihat lebih jauh bagaimana Tinjauan Yuridis Interaksi Manusia Terhadap Digital Dalam Penegakan Hukum Di Era Revolusi Industri 4.0.

\section{METODOLOGI PENELITIAN}

\subsection{Jenis Penelitian}

Pada penelitian ini menggunakan jenis penelitian normatif yaitu sebuah bentuk/jenis penelitian yang mengandalkan data dan informasi tentang hukum, baik bahan hukum primer, bahan hukum sekunder maupun bahan hukum tersier.

Bahan hukum primer yaitu bahan hukum yang sifatnya mengikat dan berkaitan erat dengan masalah-masalah yang akan diteliti, berupa peraturan perundang-undangan seperti Undang-Undang Dasar Negara Republik Indonesia tahun 1945, Undang-undang Nomor 11 Tahun 2008 tentang Informasi dan Transaksi Elektronik (UU ITE) dan Kitab Undang-Undang Hukum Pidana (KUHP).

Bahan hukum sekunder yaitu bahan hukum yang memberikan penjelasan terhadap bahan hukum primer, yaitu hasil karya di kalangan hukum yang ada relevansinya dengan masalah-masalah yang akan diteliti berupa buku-buku, pendapat-pendapat para sarjana.

Bahan hukum tersier atau bahan hukum penunjang yaitu bahan hukum yang memberikan petunjuk atau penjelasan bermakna terhadap bahan hukum primer dan bahan hukum sekunder, yaitu kamus hukum, ensiklopedia, majalah, media massa, internet dan sebagainya.

\subsection{Alat Pengumpul Data}

Penelitian ini dilakukan dengan menggunakan suatu penelitian Kepustakaan (library research). Dalam hal ini penelitian hukum dilakukan dengan cara melakukan penelitian terhadap berbagai sumber bacaan, buku-buku, berbagai literatur dan juga peraturan perundang-undangan yang berkaitan dengan teknologi komputer atau digital. Metode library research adalah mempelajari sumber-sumber atau bahan-bahan tertulis yang dijadikan bahan dalam penelitian.

\subsection{Jalannya penelitian}

Data yang telah diperoleh selanjutnya dicatat, diedit, dipelajari, kemudian diambil inti sarinya baik berupa teori, ide, konsep maupun ketentuan-ketentuan hukum yang terkait. Selanjutnya data tersebut dikumpulkan dan disusun, serta 
dikelompokan sesuai dengan permasalahan yang diteliti. Pengolahan data didahului dengan mengadakan seleksi terhadap data yang sudah terkumpul, baik bahan data primer, skunder, dan tersier.

\subsection{Analisis data}

Untuk pengolahan data yang didapatkan dari penelusuran kepustakaan, maka hasil penelitian ini menggunakan analisa kualitatif. Analisa kualitatif ini pada dasarnya merupakan pemaparan tentang teori-teori yang dikemukakan, sehingga dari teori-teori tersebut dapat ditarik beberapa hal yang dapat dijadikan kesimpulan dan pembahasan.

\section{HASIL DAN PEMBAHASAN}

\subsection{Tinjauan Yuridis Interaksi Manusia Terhadap Digital dalam Penegakan Hukum Di Era Revolusi Industri 4.0.}

Interaksi manusia terhadap digital semakin meningkat sesuai kebutuhan manusia yang semakin kompleksitas. Akan tetapi disamping dengan segala kebutuhan yang diinginkan manusia, selalu ada pemikiran-pemikiran yang negatif. Pemikiran yang negatif itu merupakan hal-hal yang mengakibatkan kerugian terhadap orang lain dengan cara menggunakan teknologo digital atau komputer. Saat ini masyarakat dunia sudah masuk dalam tahap revolusi industri 4.0, dimana kecanggihan teknologi internet menjadi pertanda yang sangat mengemuka. Teknologi tidak sekadar instrumen yang membantu manusia melaksanakan tugastugas yang kompleks, tetapi memiliki dampak perubahan revolusioner dalam pola berpikir dan berperilaku manusia serta budaya dan peradaban masyarakat. Teknologi digital saat ini tentunya memiliki efek positif dan negatif, bagaikan dua sisi mata pisau. Interaksi manusia dan komputer atau human computer interaction atau disingkat $\mathrm{HCI}$ adalah disiplin ilmu yang mempelajari hubungan antara manusia dan komputer yang meliputi perancangan, evaluasi, dan implementasi antarmuka pengguna komputer agar mudah digunakan oleh manusia. Ilmu ini berusaha menemukan cara yang paling efisien untuk merancang pesan elektronik. Sedangkan interaksi manusia dan komputer sendiri adalah serangkaian proses, dialog dan kegiatan yang dilakukan oleh manusia untuk berinteraksi dengan komputer yang keduanya saling memberikan masukan dan umpan balik melalui sebuah antarmuka untuk memperoleh hasil akhir yang diharapkan.

Diperlukan ketegasan dan penegakan hukum dalam hubungan interaksi manusia terhadap digital. Tampa dilandasi hukum maka akan terjadi hal-hal yang merugikan pihak lain dan bahkan negara. Kejahatan dunia maya (cyber crime) ini muncul seiring dengan perkembangan teknologi informasi yang begitu cepat. Cyber crime adalah segala macam penggunaan jaringan komputer untuk tujuan criminal dan/atau criminal berteknologi tinggi dengan menyalahgunakankemudahan teknologi digital (Abdul Wahid 2005, 40). Unsur objektif dalam hal perumusan delik cybercrime mengalamai beberapa terobosan dari sifat-sifat umum dari KUHP. Hal ini disebabkan kegiatan cyber meskipun bersifat virtual tetapi kategori sebagai tindakan dan perbuatan hukum yang nyata (Budi Suhariyanti 2013, 103). 
Di internet hukum itu cyber law, hukum yang khusus berlaku di dunia cyber. Secara luas cyber law bukan hanya meliputi tindak kejahatan di internet, namun juga aturan yang melindungi para pelaku e-commerce, e-learning, pemegang hak cipta, rahasia dagang, paten, e-signature, dan masih banyak lagi (Merry Magdalena 2017, 23). Interaksi Manusia Terhadap Digital dan teknologi komputer dalam Penegakan Hukum Di Era Revolusi Industri 4.0 perlu landasan hukum yang jelas dan tegas. Tindak pidana siber ialah semua tindak pidana yang menggunakan sarana atau dengan bantuan Sistem Elektronik. Itu artinya semua tindak pidana konvensional dalam Kitab Undang-Undang Hukum Pidana sepanjang dengan menggunakan bantuan atau sarana Sistem Elektronik seperti pembunuhan, perdagangan orang, dapat termasuk dalam kategori tindak pidana siber dalam arti luas. Akan tetapi, dalam pengertian yang lebih sempit, pengaturan tindak pidana siber diatur dalam Undang-Undang Nomor 11 Tahun 2008 tentang Informasi dan Transaksi Elektronik sebagaimana yang telah diubah oleh Undang-Undang Nomor 19 Tahun 2016 tentang Perubahan Atas Undang-Undang Nomor 11 Tahun 2008 tentang Informasi dan Transaksi Elektronik.

\subsection{Penyebab terjadinya Penyalahgunaan Interaksi Manusia Terhadap Digital di Era Revolusi Industri 4.0.}

Adapun yang menjadi penyebab terjadinya Penyalahgunaan Interaksi Manusia Terhadap Digital di Era Revolusi Industri 4.0. antara lain :

a. Akses internet yang tidak terbatas, sekarang ini internet bukanlah hal yang langka lagi, karena semua orang telah memanfaatkan fasilitas internet. Dengan menggunakan internet kita diberikan kenyamanan kemudahan dalam mengakses segala sesuatu tanpa ada batasannya. Dengan kenyaman itu lah yang merupakan faktor utama bagi sebagian oknum untuk melakukan tindak kejahatan Cybercrime dengan mudahnya.

b. Kelalaian pengguna komputer. Hal ini merupakan salah satu penyebab utama kejahatan komputer. Seperti kita ketahui orang-orang menggunakan fasilitas internet selalu memasukan semua data-data penting ke dalam internet. Sehingga memberikan kemudahan bagi sebagian oknum untuk melakukan kejahatan.

c. Mudah dilakukan dengan alasan keamanan yang kecil dan tidak diperlukan peralatan yang super modern. Inilah yang merupakan faktor pendorong terjadinya kejahatan di dunia maya. Karena seperti kita bahwa internet merupakan sebuah alat yang dengan mudahnya kita gunakan tanpa memerlukan alat-alat khusus dalam mengunakannya. Namun pendorong utama tindak kejahatan di internet yaitu susahnya melacak orang yang menyalahgunakan fasilitas dari internet tersebut.

d. Para pelaku merupakan orang yang pada umumnya cerdas, mempunyai rasa ingin tahu yang besar dan fanatik akan teknologi komputer. Pengetahuan pelaku kejahatan komputer tentang cara kerja sebuah komputer jauh diatas operator komputer.

e. Sistem keamanan jaringan yang lemah. Seperti kita ketahui bahwa orang-orang dalam menggunakan fasilitas internet kebanyakan lebih mementingkan desain yang di milikinya dengan menyepelekan tingkat keamanannya. Sehingga dengan 
lemahnya sistem keamanan jaringan tersebut menjadi celah besar sebagian oknum untuk melakukan tindak kejahatan.

f. Kurangnya perhatian masyarakat dan penegak hukum. Pada kenyataannya para pelaku kejahatan komputer masih terus melakukan aksi kejahatannya. Hal ini disebabkan karena rendahnya faktor pengetahuan tentang penggunaan internet yang lebih dalam pada masyarakat.

\subsection{Upaya Pencegahan Penyalahgunaan Interaksi Manusia Terhadap Digital di Era Revolusi Industri 4.0.}

Interaksi manusia terhadap digital atau teknologi komputer terjadi begitu dinamis tampa ruang batas. Interaksi manusia terhadap digital atau teknologi komputer sangat memungkinkan terjadinya kejahatan komputer sehingga perlu pencegahan yang harus dilakukan baik bagi diri sendiri maupun Pemerintah Republik Indonesia. Cybercrime merupakan satu tindakan yang merugikan orang seseorang atau instansi yang berkaitan dan pengguna fasilitas dengan sistem informasi yang bertujuan untuk menguntungkan dirinya sendiri atau orang lain, sehingga cybercrime ini termasuk dalam tindak kejahatan sehingga diatur dalam Undang-undang Nomor 11 tahun 2008, tentang informasi dan transaksi elektroik.kejahatan ini harus diwaspadai karena kejahatan ini berbeda dengan kejahatan lainnya. Cybercrime dapat dilakukan tanpa mengenal batas tritorial dan tidak memerlukan interaksi langsung antar pelaku dengan korban kejahatan.Sehingga bisa dipastikan dengan dengan global internet, semua negara yang melakukan kegiatan internet akan terkena imbas perkembangan cybercrime ini. Berikut beberapa hal yang harus dilakukan upaya pencegahan penyalahgunaan kemudahan teknologi digital, yaitu :

a. Mengamankan system, Langkah awal yang perlu dilakukan oleh para pengguna teknologi internet dalam upaya penanggulangan cybercrime adalah melidungi dari kejahatan dengan mengamankan sistem komputer.

b. Penanggulangan Global, Saat ini upaya yang dipersiapkan untuk memerangi cybercrime. Dari berbagai upaya yang dilakukan tersebut, jelas bahwa cybercrime membutuhkan global action dalam penanggulangnnya. Ada beberapa langkah yang harus dilakukan setiap Negara dalam penanggulangnnya, yaitu :

1. Melakukan moderenisasi hukum pidana nasional beserta hukum acaranya, yang diselaraskan dengan konvensi internasional yang terkait dengan kejahatan tersebut.

2. Meningkatkan sistem pengamanan jaringan komputer nasional sesuai standar internasional.

3. Meningkatkan pemahaman serta keahlian aparatur penegak hukum mengenai upaya pencegahan, investigasi dan penuntutan perkara-perkara yang berhubungan dengan cybercrime.

4. Meningkatkan kesadaran warga negara mengenai masalah cybercrime serta pentingnya mencegah kejahatan tersebut.

5. Meningkatkan kerjasama antar negara, baik bilateral, regional, maupun multilateral, dalam upaya penanganan cybercrime, antara lain melalui perjanjian ekstradisi dan mutual assistance treaties. 
c. Perlunya Cyberlaw, Perkembangna teknologi yang sangat pesat, membutuhkan membutuhkan pengaturan yang berkaitan dengan pemanfaatan teknologi tersebut seperti Undang-undang Nomor 11 Tahun 2008. Peraturan ini sangat diperlukan dikarenakan begitu banyak pelanggrang yang dilakukan dalam dunia maya saat ini.

d. Perlunya dukungan lembaga khusus, baik milik negara maupun NGO (Non Goverment organization).

\section{KESIMPULAN}

Interaksi manusia terhadap digital semakin meningkat sesuai kebutuhan manusia yang semakin kompleksitas. Saat ini masyarakat dunia sudah masuk dalam tahap revolusi industri 4.0, dimana kecanggihan teknologi internet menjadi pertanda yang sangat mengemuka. Teknologi tidak sekadar instrumen yang membantu manusia melaksanakan tugas-tugas yang kompleks, tetapi memiliki dampak perubahan revolusioner dalam pola berpikir dan berperilaku manusia serta budaya dan peradaban masyarakat. Teknologi digital saat ini tentunya memiliki efek positif dan negatif, bagaikan dua sisi mata pisau. Interaksi manusia dan komputer atau human computer interaction atau disingkat HCI adalah disiplin ilmu yang mempelajari hubungan antara manusia dan komputer yang meliputi perancangan, evaluasi, dan implementasi antarmuka pengguna komputer agar mudah digunakan oleh manusia. Interaksi Manusia Terhadap Digital dalam Penegakan Hukum Di Era Revolusi Industri 4.0 perlu landasan hukum yang jelas dan tegas. Tinjauan hukum yang menjadi landasan dasar dalam penyalahgunaan digital atau teknologi komputer yaitu Kitab Undang-Undang Hukum Pidana (KUHP) dan Undang-Undang Nomor 11 Tahun 2008 tentang Informasi dan Transaksi Elektronik sebagaimana yang telah diubah oleh Undang-Undang Nomor 19 Tahun 2016 tentang Perubahan Atas Undang-Undang Nomor 11 Tahun 2008 tentang Informasi dan Transaksi Elektronik. Penyebab terjadinya Penyalahgunaan Interaksi Manusia Terhadap Digital di Era Revolusi Industri 4.0. antara lain yaitu Akses internet yang tidak terbatas, Kelalaian pengguna computer, Mudah dilakukan dengan alasan keamanan yang kecil dan tidak diperlukan peralatan yang super modern, Para pelaku merupakan orang yang pada umumnya cerdas, Sistem keamanan jaringan yang lemah, dan Kurangnya perhatian masyarakat dan penegak hukum. Upaya Pencegahan Penyalahgunaan Interaksi Manusia Terhadap Digital di Era Revolusi Industri 4.0 dapat dilakukan dengan dukungan lembaga khusus, baik milik negara maupun NGO (Non Goverment organization).

\section{DAFTAR PUSTAKA}

[1] Sinta Dewi Rosadi, Cyber Law Aspek Data Privasi menurut Hukum Internasional, Regional, dan Nasional, Refika Aditama, Bandung, 2015.

[2] Widodo, Sistem Pemidanaan dalam Cyber Crime Alternatif Ancaman Pidana Kerja Sosial dan Pidana Pengawas bagi Pelaku Cyber Crime, Laksbang Mediatama, yogyakarta, 2009.

[3] Barda Nawawi Arief, Perlindungan HAM dan Korban dalam Pembaharuan Hukum, Citra Aditya Bakti, Bandung, 2000.

[4] Abdul Wahid dan Mohammad Labib, Kejahatan Mayantara (Cyber Crime), (Jakarta: PT. Refika Aditama, 2005. 
[5] Budi Suhariyanto, Tindak Pidana Teknologi Informasi (Cyber Crime) Urgensi Pengaturan dan Celah Hukumnya, Rajawali Pers, Jakarta, 2013.

[6] Merry Magdalena dan maswigrantoro Roes Setiayadi, Cyberlaw, Tidak Perlu Takut, ANDI, yogyakarta, 2007. 